\title{
Will genomics erode public health and prevention? A scenario of unintended consequences in the Netherlands
}

\author{
Tilo Propp and Ellen H M Moors
}

\begin{abstract}
In Dutch health policy, new visions of future healthcare paradigms have been articulated over the past decade, where a multi-disciplinary knowledge base is expected to feed into prevention and treatment, responding to socio-economic health pressures whilst configured around the individual patient's needs. However, in parallel, life sciences research has undergone changes since the completion of the Human Genome Project. Increased knowledge of the human genome is expected to enable the development of drugs tailored to individual genotype, and improve treatment of chronic disorders. With much attention and science funding focused on the expected, but largely uncertain, contributions of genomics to healthcare, one may ask if we are witnessing unintended consequences, i.e. the slow erosion of public health and prevention? This paper uses colorectal cancer (also called colon or rectal cancer) genomics to demonstrate how visions of 'personalized healthcare' have been created around genomics that are essentially uncertain, while ongoing genomics funding affects other life science areas aligned with prevention. We sketch out better approaches to expectations management based on scenario building and policy coordination.
\end{abstract}

$\mathrm{T}$ HE HUMAN GENOME PROJECT (19902003) led to the identification of all genes contained in the human DNA and their structural and functional aspects. ${ }^{1}$ The genome is an organism's set of DNA. Genomics is often used as an umbrella term for a number of structural and functional studies of genes and proteins using large-scale differential gene/protein expression platforms (micro arrays). A number of 'big science' projects have since contributed further insights, focusing on the catalogue of human genetic variations (the SNP Consortium); genotyping variations in individuals (the International HapMap Project); and large-scale protein analysis (as lobbied for by the Human

\footnotetext{
Dr Tilo Propp (corresponding author) and Dr Ellen H M Moors are both at the Copernicus Institute/Department of Innovation and Environmental Studies, Utrecht University, Van Unnik Building, P.O. Box 80.115, 3508 TC Utrecht, the Netherlands; Email: tilo5@gmx.de.

This research is part of the programme of the Center for Society and Genomics (CSG), Nijmegen, the Netherlands, and was funded by the Netherlands Genomics Initiative (NGI).
}

Proteome Organisation) (Cardon and Watkins, 2000: 1223; International SNP Map Working Group, 2001: 928; Palmer, 2004: 925; Abbott, 2001: 747; Chandonia and Brenner, 2006: 347, 350).

Labels such as 'personalized medicine' have come to express expectations of novel diagnostic and therapeutic products and ways of dealing with chronic disorders. With respect to pharmaceutical innovation, genomics is seen as a tool for finding novel drug targets and predicting and treating especially chronic disorders with greater sensitivity to individual genotype (Ginsburg and McCarthy, 2001: 491; Nebert and Bingham, 2001: 519). Some actors in the Netherlands see genomics as the solution to a number of challenges, such as demographic shifts towards an older population and the growing role of age-related disorders, and economic and health costs of trial-and-error treatments and drug non-response (NGI, 2006: 19, 33; MinEZ, 2006: 32; Senter-Novem, 2008: 42; MinVWS, 2007a: 10; MinEZ/TWA Network, 2006: 3; RVZ, 2001a: 21; RVZ, 2001b: 12; KNMG, 2007: 3).

Over the past five years, learning has taken place about the likely benefits and limitations of genomics, 
Tilo Propp received his MA and $\mathrm{PhD}$ in social history from Rostock University, Germany. He worked at the universities of Potchefstroom and Stellenbosch (South Africa) on the relationship between inter-disciplinary collaboration and friction in social development projects, and science-andtechnology-in-society issues, respectively. At Twente University (the Netherlands) he focused on assessment activities and dynamics of new and emerging science and technology, especially biomedical applications of micro- and nanofluidics. Currently at Utrecht University, he studies genomics-based expectations of personalized health in strategic research and research and development (R\&D) management and as a means of de facto agenda setting in contrast to elaborated visions of healthcare.

Ellen $\mathrm{H}$ M Moors studied biochemistry at the University of Nijmegen, the Netherlands. She received a PhD in science, technology and innovation studies from Delft University of Technology. Since 2001 she has been working at the Department of Innovation Studies at Utrecht University, studying innovation processes in biotechnology developments and healthcare, focusing on technology dynamics and interaction processes, both from a firm's and a user-producer perspective. She is currently an associate professor of innovations in life sciences and health. She also coordinates the life sciences educational track in the undergraduate programme in science and innovation management.

and the pre-conditions that enable genomics-based research and innovation. These include: ancillary technological innovations, R\&D strategies of companies, the regulatory environment, and ethical issues and societal concerns. However, with statements as recent as 2008 that genomics 'creates realistic expectations of new therapeutic treatments in the next ten years' (NGI, 2008: 33), the essential uncertainties and nonlinearity of the innovation processes are still being glossed over, at least in public communication. Care is being taken that representative documents (business plans, annual reports) relating to fundamental research institutes or science-to-industry consortia are disseminated broadly. However, the labels of projected genomics-based products will stick with readers, especially those to whom such expectations are of existential value, such as patients suffering from chronic disorders. What may escape these patients' attention is the fact that expectations are not only communicated as forms of anticipation of the future, but also as a

\section{What may escape these patients' attention is that expectations are not only communicated as forms of anticipation of the future, but also as a means to sustain policy-making interest in fundamental research that is still far from applications in therapies, and needs huge investments}

means to sustain policy-making interest in fundamental research that is still far from applications in therapies, and needs high investments.

There are now indications that the current investments in genomics research, infrastructure and research do affect other disciplines: by directing funds to genomic projects, or expecting research projects to include a genomic component or genome-related approach. In addition, there is the question how these developments in fundamental science and science policy impact concurrent developments in other Dutch policy sectors, such as health policy. The future visions of healthcare articulated here require a knowledge base more comprehensive than molecular biology.

There is a need for better approaches to the responsible generation and communication of expectations, informed by knowledge of the pre-conditions and strategies required for the realization of expectations. A broad, socially inclusive process of scenario building can inform the generation of expectations. Science and innovation policy scholars can address these gaps. We will build our argument for policyoriented engagement with genomics expectations based on a combination of literature studies (innovation studies, policy studies, and the cancer genetics and epidemiology literature), interviews with experts in Dutch fundamental cancer research, epidemiology, clinical research, and technology transfer and policy-making, and the application of a specifically adapted framework for mapping expectations. Our paper is the first to apply such a framework to the mapping of genomics expectations, and to make suggestions regarding genomics expectations management

First, we sketch out current health policy developments in the Netherlands. There are attempts at creating visions of future healthcare that require a multi-disciplinary knowledge base expected to feed into evidence-based prevention, diagnostics, and treatment of chronic disorders. This knowledge base is notably broader than molecular biology. Since 2000, the latter has received much attention in life science policy-making. We will sketch out the development of genomics programmes in the Netherlands. We then categorize and describe the different kinds of genomics expectations at different levels. Using a conceptual framework derived from expectations studies, we introduce the distinction between 'product' and 'paradigm expectations' of 'personalized health', and illustrate these expectations. We use colorectal cancer as a case study to describe the progress, limitations and uncertainties of cancer genomics as measured against expectations of personalized prevention and treatment. We outline the structural impacts of genomics funding on health policy developments. Finally, we describe the challenges to which policy-makers have to respond, and suggest how to initiate or improve expectations management, scenario building, and policy coordination across different policy sectors. 


\section{Health policy developments}

In Dutch health policy there is growing attention to the prevention of chronic disorders. Sector councils and advisory bodies have stressed in recommendations to government departments (such as the Ministry of Health, Welfare and Sports) the importance of prevention, including for example pre-symptomatic screening for genetic risk factors and lifestyle modification (including diet) (RVZ, 2002a: 38-39). They have also expressed the view that more effective prevention would yield a greater public health benefit than the stimulation of more efforts in the curative sector (RGO, 2001: 19). Developing a new policy on predictive medicine, preventive screening and testing was named as one of the policy themes of the Ministry of Health, Welfare and Sport for the period 2007-2011 (MinVWS, 2007b: 14). Here, we give a broad overview of these developments.

Programmes Family practitioners are most effective in persuading patients to take part in preventive measures (KNMG, 2007: 8) but are hampered by lack of scientific evidence about effective prevention methods (RIVM, 2006: 111). In terms of research on prevention ZonMw (the Netherlands Organisation for Health Research and Development; the programme coordinator and funding agency for the Ministry of Health, Welfare and Sports) has been coordinating two large prevention programmes (1998-2002, 2005-2008). A third programme is in preparation, focusing on primary (modification of disorder triggers and determinants) and secondary prevention (pre-symptomatic identification and treatment of potential disorders). ${ }^{2}$ These types of prevention require reliable knowledge of determinants of disorder as well as health. More research and testing are necessary in order to allow for 'evidence-based' prevention measures (ZonMw, 2006: 2, 9). Population screening for chronic disorders is part of secondary prevention measures (ZonMw, 2008b: 11, 17). Screening in risk groups (defined by age and socio-economic conditions) is currently undertaken with respect to breast and ovarian cancer, while pilot trials in colorectal cancer screening have started (RIVM, 2006: 104-105). Another ZonMw programme is targeting prevention of chronic disorders, 'Food and Health' (Voeding en Gezondheid) was started in 2008; its activities will be complementary to research in public-private partnerships (ZonMw, 2008a: 54).

Visions RIVM (the Dutch National Institute for Public Health and the Environment) recommended a 'life-course perspective' on the relationship between individual and disorder prevention. In the course of one's life an individual passes through different forms of prevention related to different disorder categories prevalent at that stage, such as pre-natal screening for treatable monogenetic disorders like phenylketonuria (PKU), prevention of mental disorders in adulthood, and cancer screening in midand old-age. A 'life-course' approach would embed individual life trajectories in the larger social circumstances at different stages of life, thus integrating individual and population-level measures (RIVM, 2006: 15, 111-112, 165). Other labels, such as 'disease management' or 'integrated care' have been used to refer to the integration of prevention into comprehensive approaches to treating chronic disorders while putting the patient and his/her needs at the centre of attention. These labels are not new but there are still different understandings of what they refer to (Mason et al., 1999; Weingarten et al., 2002). ZonMw defines 'disease management' as a broad approach to chronic disorder management, characterized by an integrated chain of activities comprising diagnostics, prevention, early detection, treatment, and self-management, as well as adjusted management and financial structures (these are the hallmarks of disease management). The agency currently coordinates, inter alia, a collaborative disease management programme that also targets cancer. ZonMw sees the knowledge base of prevention emerging from multi-disciplinary activities (ZonMw, 2008b: 7, 10, 13, 17-18). This can be a combination of epidemiological research focusing on food-health relationships, and genetics (RVZ, 2001b: 77), increasingly referred to as 'translational research' (KNAW-MFA, 2006: 48, 101).

\section{Genomics programmes, 2000-2008}

Large-scale funding of genomics was initalized in 2000-2001 (broader developments in current Dutch biotechnology are discussed in van der Valk et al., 2009). The Innovation Oriented Research Program (IOP) Genomics was set up in autumn 2000. The activities in the current second phase of this programme include a focus on research into genedisease relationships in chronic disorders, which are seen as central to the development of improved drugs, and the functionalities of foods (SenterNovem, 2004: 17, 43).

In 2001 the Netherlands Genomics Initiative (NGI) was established based on the recommendations of the Temporary Advisory Commission Knowledge Infrastructure Genomics (the 'Wijffels Commission'; Tijdelijke Adviescommissie..., 2001: 5-6; MinOCW, 2001: 1). NGI's functions were defined as: articulation and execution of a national genomics strategy, including collaboration with funding agencies, and coordination of other genomics-related programmes (NGI, 2008: 7; MinEZ/Task Force Life Sciences en Gezondheid, 2008a: 45). Interestingly, from the perspective of molecular biologists, by 2002 it had already become clear that the 'genomics' concept is too narrow to understand disease pathways; instead 'structural biology' (the integration of research at different molecular levels) is needed (interviewee D). ${ }^{3}$ Simultaneously, for some 
policy-makers it was not yet clear what 'genomics' meant (interviewee G). The number of research consortia and networks coordinated by NGI grew and diversified from 2001-2002 onward to today include 'centers of excellence' (networks of fundamental research groups), 'innovative clusters' (mostly public-private consortia), and 'technology centers' (development of technological platforms and infrastructures) (NGI, 2008: 19, 22; SenterNovem, 2004: 18-19). For the current (2008-2012) period NGI receives $€ 280 \mathrm{~m}$ in government funds; it is expected that this amount will attract additional investments (industry; academia; research institutes) bringing the total budget close to $€ 500 m$ (NGI, 2007b: 2; 2008: 6).

Next to IOP Genomics and NGI are publicprivate partnerships, comprising universities, research institutes, and leading companies. With shared public-private funding these partnerships are characteristic of the third phase of innovation policy, the coordinated interplay of market and non-market forces (Braun, 2008a: 227): the Center for Molecular Medicine (CTMM), the Biomedical Materials Programme, and the two Top Institutes (TI) Pharma and TI Food and Nutrition (TIFN). ${ }^{4}$ Their budgets are considerable: TI Pharma: €230m; CTMM: €400m; Biomedical Materials: €90m (all 2006; MinEZ/Task Force..., 2008a: 22; 2008b). The 'Food and Nutrition Delta' programme of the Ministry of Economic Affairs has a budget for 2007-2010 of €50.8 million, ${ }^{5}$ which has led to the creation of TIFN. Initially, the creation of TIs was opposed by academia and the main research funding agency in the Netherlands, the Netherlands Organisation for Scientific Research (NWO) because of the high investments (van der Meulen and Rip, 1998: 759-760; see also Lepori et al., 2007: 381). These institutes position themselves as efforts focusing on particular innovation fields in the broader life sciences area (drugs; diagnostics; devices) vis-à-vis NGI, which is seen as doing explorative and strategic research (TI Pharma, 2007: 37; NGI, 2007a: 11). However, with respect to the publicly funded research programmes calls for more emphasis on valorization have become louder (Senter-Novem, 2004: 8).

\section{Genomics-enabled research and innovation: expectations and uncertainties}

The expectations landscape in genomics is complex. One has to differentiate between search, product and paradigm expectations as well as the contents of these expectations, which can differ depending on how the elements of diagnosis, prevention and treatment feature in paradigm expectations. In this section, we will first develop a conceptual framework for the mapping of expectations, based on contributions from the expectations dynamics literature. We will then give an overview of general and cancer-specific expectations in the life sciences lit- erature and at the level of the Cancer Genomics Centre $(\mathrm{CGC})^{6}$ in the Netherlands. A case study of colorectal cancer (cancer of the large intestine, which comprises the colon and the rectum) will help us to consider the uncertain future role of genomics in cancer health care. We add the results of document analyses focusing on the acknowledgement of these uncertainties.

\section{Expectations and their functions}

We define expectations as any kind of statement about the future outcomes of an ongoing (or planned) activity or a series of events initiated to achieve a goal, and the effectiveness of these measures. While 'aspirations' describe the chosen goal, 'expectations' are assessments of probabilities and strategies. Expectations studies provide concepts for understanding, mapping, and possibly managing expectations. Van Lente (1993: 66-70), 182-183) identified three types of expectations categories, layered concentrically around ongoing or intended activities. We have adapted his categories to apply to fundamental science:

- 'Search expectations' are statements about strategies that seem best to answer a particular fundamental question. This sort of 'informed guesswork' is intrinsic to fundamental science and accumulates over time, through trial-and-error, a track record of proven strategies.

- 'Product expectations' are related to outcomes in terms of diagnostic tools, therapies etc. Fundamental research is not necessarily concerned with product development: the outcomes of research in several lines in different fields may be necessary to create such products.

- 'Paradigm expectations' are related to visions of future healthcare. The above products, but also accepted practices, resolved ethical conflicts, ways of thinking about health-disorder relationships and individual and public health responsibility, and financial and regulatory arrangements have their place in, or sustain, these visions.
The expectations landscape in genomics is complex. One has to differentiate between search, product and paradigm expectations as well as the contents of these expectations, which can differ depending on how diagnosis, prevention and treatment feature in paradigm expectations 
Differentiating product and paradigm expectations is useful since paradigm labels such as 'personalized health/medicine' are not clearly defined, and can comprise different constituent product elements, in turn implying different innovation trajectories. However, differentiating product and paradigm expectations can be difficult if homonyms ("medicine"7) are used for both. In this paper, we will only deal with product and paradigm expectations of genomics, their pre-conditions and expectations management.

In order to understand the meaning of expectations statements, two functions need to be distinguished. Firstly, an expectation is an anticipation of the likely future. Experience may tell us in some instances which predictions or trend extrapolations are likely, however, as the results have not occurred yet, a degree of uncertainty remains. Secondly, expectations have a performative function (Brown et al., 2003: 3): they are part of camouflaged strategies of mobilizing the support of other actors for specific ongoing or intended activities (van Lente, 1993: 51). Researchers, for example, suppress possibilities of alternative futures, compress the nonlinearity of innovation into a linear, well-sequenced activity, and present uncertain product and paradigm anticipations as certain: hoping for the alignment of other actors and the resources they have or can distribute around these expectations.

\section{General and cancer-specific expectations of} genomics-enabled research and innovation

In the emerging field of pharmacogenomics, expectations are related to the potential of genomics as a tool for finding novel drug targets and predicting and treating especially chronic disorders with greater sensitivity to individual genotype (Ginsburg and McCarthy, 2001: 491; Nebert and Bingham, 2001: 519). These disorders have polygenetic variations as a background but are triggered by environmental or

\section{A number of labels have emerged that refer to the paradigm expectations of future healthcare: 'personalized health', 'prospective/personalized healthcare', and 'prospective', 'predictive', 'genomic' or 'molecular medicine'. The most encompassing paradigm expectations combine personalized prevention and therapeutic care}

lifestyle factors (diets, alcohol, nicotine, exposure to chemical substances). 'Nutrigenomics' is expected to go beyond the limits of traditional biochemistry and contribute novel approaches to studying genenutrition relationships and development of novel foods designed around a patient's genotype (personalized nutrition) (Kussmann et al., 2006: 758; Roberts et al., 2001: 516; Simopoulos, 2002: S117).

A number of labels have emerged that refer to the paradigm expectations of future healthcare: 'personalized health', 'prospective/personalized healthcare', and 'prospective', 'predictive', 'genomic' or 'molecular medicine'. The most encompassing paradigm expectations relate to the combination of personalized prevention and therapeutic care whereby 'personalized nutrition' is central to prevention (see Figure 1). The most commonly described elements of personalized healthcare are as follows:

- Personalized healthcare would be initiated at a very early age by using sets of genes or proteins with high correlations to types of cancer (genomic

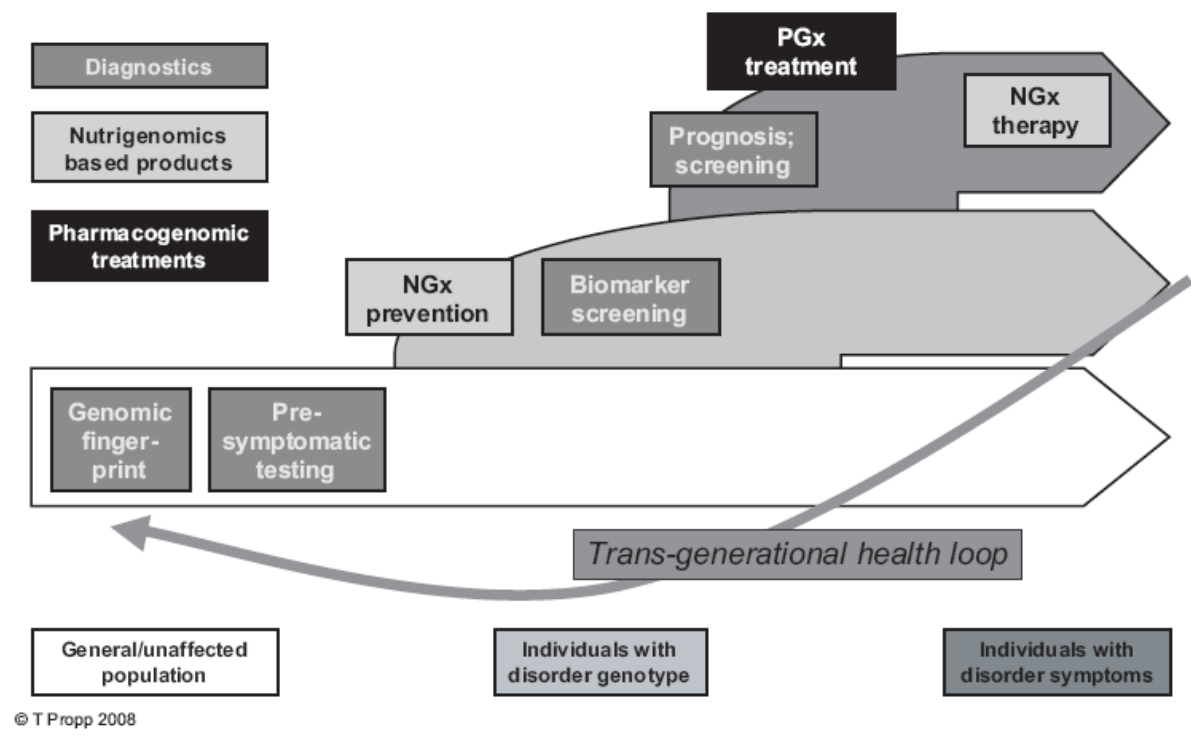

Figure 1. Elementary activities in visions of 'personalized health'8 
fingerprints), allowing for molecular differentiation of diseases with similar clinical phenotypes and risk prediction (Ginsburg and McCarthy, 2001: 493; Roberts, 2002: S87). Several techniques are already available (Kussmann et al., 2006: 778; Anderson, 2002: 321; Rist et al., 2006: 174).

- Knowledge of molecular biomarkers of inherited disorders would enable periodical presymptomatic testing. Biomarkers are diverse sets of molecules indicating exposure, effects, and susceptibility to a disease, helping to discriminate between subjects who remain cancer-free and those who develop cancer, or to ascertain how far a disease has progressed (Colditz et al., 2006: 80; van Ommen and Stierum, 2002: 518; Rist et al., 2006: 175). Currently, parents can make use of a number of pre- and postnatal testing and screening techniques (see Davey Smith et al., 2005: 1485-1487) but the gene-disease pathways are not sufficiently known yet for many diseases, thus hindering the development of tests (Clydesdale, 2004: 37).

The diagnostic measures above would aim to differentiate those individuals without a disorder genotype from those with a disorder genotype. The latter would be advised on:

- Nutrigenomic prevention: The individual profile of the variations of genes involved in the metabolism of specific diets and nutrients would constitute the basis of preventative lifestyle advice including recommendations which types of foods to consume or avoid (Ginsburg and McCarthy, 2001: 491, 493; Khoury et al., 2004: 937). For monogenic disorders (PKU, galactosemia) foodbased prevention is already available and the phenotype can be altered (Kussmann et al., 2006: 768; Jorde et al., 2006: 62).

Prevention would aim at differentiating individuals with disorder genotype from those who actually develop the disorder. For the latter:

- A prognosis would be made, and the progress of the disease studied using molecular biomarkers. This would help to 'tailor' therapy for individuals with an aggressive form/rapid progression vis-àvis those with slower progression (Ginsburg and McCarthy, 2001: 493).

- Genotype-directed drug treatment would replace current trial-and-error methods of selecting drugs for treatment (Ginsburg and McCarthy, 2001: 491, 493). Patients would receive medicine tailored to their molecular profile and at the right doses (Berry, 2001: 240; Nebert and Bingham, 2001: 519), and would be advised on nutrigenomic therapies.

Finally, health investments in the parent generation would pay off in the offspring generation (transgenerational health loop).
Pre-symptomatic intervention and tailorization to the individual genome characterize the version of 'personalized health' presented here. Nutrigenomic products are expected to play major roles in both prevention and treatment; however, nutrigenomics does not always feature in visions of personalized health. Nutrigenomics is marginal where personalized treatment is the focus, as in the case of expectations in official documents of the Cancer Genomics Centre (CGC) in the Netherlands.

The CGC is a network of internationally highly visible research groups based at the University Medical Centre Utrecht; the Netherlands Cancer Institute (Amsterdam); the Erasmus Medical Center (Rotterdam); and the Hubrecht Institute, Utrecht (a research institute of the Royal Netherlands Academy of Arts and Sciences). It is part of the NGI. In the CGC's first periodic activity report (CGC, 2006), expectations of genomics have been framed in a way that does not include any of the above references to nutrigenomics and prevention. The CGC's aspiration is to address therapy failure of the traditional systemic treatment of tumor patients; the primary objective (as stated in the report) is research-based, i.e. understanding the genetic changes implied in tumorigenesis and identifying predictive markers for resistance (CGC, 2006: 9, 40). Researchers' relationships with product and paradigm expectations in cancer genomics are ambiguous. While the researchers at the CGC refrain from engaging in these farreaching expectations (interviewee $\mathrm{D}$ ), some form of alignment with the right type of expectations increases the chances of receiving funding (interviewees $\mathrm{B}$ and $\mathrm{H}$ ). This may explain an existing, though rather tentative, alignment with product and paradigm expectations. The genomic signature of both the cancer (tumor/s) and that of the patient '... may serve in the near future as a basis on which to choose the most effective therapy for the individual patient ('personalized medicine') to improve cancer patients chances of recovery and their quality of life' (CGC, 2006: 9; confirmed by interviewees $C$ and D). Molecular biologists stress the inevitability of cancer due to inherited cancer predisposition. This renders prevention essentially unimportant. Thus, paradigm expectations vary with respect to the type of personalized health envisaged in the context of a particular disorder.

However, it is not only the disorder at hand that modifies expectations of genomics-enabled innovation. There are further uncertainties, which can have a more fundamental impact on these expectations. We will illustrate these uncertainties below in a case study of colorectal cancer.

\section{Colorectal cancer and the uncertainties of personalized health}

Colorectal cancer (the cancer of the large intestine comprising the colon and the rectum) is among the more commonly diagnosed neoplastic conditions ${ }^{9}$ in 
both sexes. During the 20th century mortality rates have declined but the overall prevalence of colorectal cancer has increased (Baglioni and Genuardi, 2004: 35). By the ago of 70, about half of the male and female population in industrialized countries will have benign tumors of the distal gastrointestinal tract (adenomas), and about one in ten patients will progress to malignancy (Cardoso et al., 2007: 103). A number of Dutch health programmes and initiatives previously or recently coordinated by ZonMw and IOP Genomics had or have direct relevance for colorectal cancer (ZonMw, 2008b: 10, 13; Senter-Novem, 2004: 43).

Epidemiology, aetiology, risk prediction and prevention The evolution of colorectal cancer takes place in multiple steps driven by specific genetic variations, from normal cells via benign adenomas to malignant carcinomas, and eventually metastasis. Only up to $15 \%$ arise from pre-malignant conditions inherited as singular genetic changes (such as familial adenomatous polyposis, hereditary non-polyposis colorectal cancer). Screening for these conditions can help predicting cancer risk with some measure of certainty. However, prediction is more difficult for sporadic cancers: up to $85 \%$ are sporadic, i.e. they develop as a result of interactions between lowpenetrance genetic variations, environmental factors, and modifier genes (Baglioni and Genuardi, 2004: 35, 39; de la Chappelle, 2004: 771). The research literature emphasizes this problem of predictability (Brennan, 2002: 382), phenotype-directed intervention may therefore be more reliable than genotypebased testing (interviewee A). There are non-genetic screening tools, both invasive (colonoscopy and endoscopy) and non-invasive (occult fecal blood testing). Partial surgery is a preventive option (Baglioni and Genuardi, 2004: 35, 38). However, with the majority of colorectal cancers being sporadic, diagnosis is often at the symptomatic stage (tumors) (National Cancer Institute, 2006).

Diet has an influence on cancer development via its nutritional components, such as: fibres, omega-3 fatty acids, minerals, vitamins, plant-based bioactive substances, and probiotics. ${ }^{10}$ Diet-related factors may account for up to 30\% of cancers in industrialized countries (Christensen, 2004: 822). Environmental, dietary and lifestyle factors induce largely non-inheritable and thus reversible 'epigenetic' changes of DNA, which can also cause critical changes in cancer cells (Baglioni and Genuardi, 2004: 40; Bencko, 2007: 8; Bracken, 2005: 298). This means that prevention strategies at an early stage can be geared to limiting exposure to risk factors, or the modification of lifestyles, including diets (Herceg, 2007: 99; interviewee F). However, from a nutritional epidemiology point of view, commercially available dietary supplements will not be as effective in terms of prevention as a full diet, and would exert their protective benefits only over years (Peto, 2001: 391). More research on diet-based prevention is required (Baglioni and Genuardi, 2004: 40; WCRF/AICR, 2007: 66-196; interviewee E).

Ancillary innovation Biomarkers as predictors of cancer risk are very important. So far, most biomarkers do not work in prospective epidemiological research designs (Perera, 2000: 605). Huge infrastructure investments are required (databases, bioinformatics) in order to establish reliable markers (Ginsburg and McCarthy, 2001: 495; van Ommen and Stierum, 2002: 518). In terms of research infrastructure, 'Parelsnoer'11 (String of Pearls) can be mentioned. This is a project aimed at setting up a nationwide biobank storing clinical and molecular data and tissue involving various academic hospitals (TI Pharma, 2007: 36).

Interdisciplinary collaboration Collaboration between molecular biologists, epidemiologists and clinical researchers in pre-clinical and clinical environments is increasingly referred to as 'translational research'. It has been touted as promising but it is not clear yet what counts as translational research (KNAW-MFA, 2006: 48, 101; RGO, 2007: 24). Translation from animal models to humans is necessary but remains difficult (Baglioni and Genuardi, 2004: 39; Campbell and Manolio, 2007: 446). Fundamental differences between research designs (prospective studies versus in vitro experiments) have to be overcome (interviewee $\mathrm{M}$ ).

Economics and market dynamics of drug and food development Traditional chemotherapeutic agents are used as combinations ('FOLFIRI', 'FOLFOX') which circulate throughout the body via the blood system, hence the treatment is known as 'systemic' therapy (Kornek et al., 2008: 79-80). An emerging concept is 'targeted therapy': drugs that target signal transduction pathways, or inhibit the growth of new blood vessels in tumors, such as monoclonal antibodies and tyrosine kinase inhibitors (Yun, 2004: 181, 182, 184; Canda and Kirkali, 2006: 7; Pohl et al., 2008). Drugs are often approved for combination with traditional systemic therapies (Kornek et al., 2008; Brower, 2003: 1425; interviewee M).

\section{Collaboration between genomicists, epidemiologists and clinical researchers in pre-clinical and clinical environments is increasingly known as 'translational research'. It has been touted as promising but it is not clear yet what counts as translational research}


Targeted therapies pose problems in that for example angiogenesis inhibitors take time to work and arrest, rather than shrink, tumors (Brower, 2003: 1425).

Expression profiles of different functional gene groups, as well as the type of tumor chromosomal instability have already been used for prediction of stage II in colon cancer patients (Cardoso et al., 2007: 116, 119). These and other interventions have been referred to as 'personalized' but refer to groups or sub-populations stratified by genotypically defined drug response (Baglioni and Genuardi, 2004: 35; KNAW-RMW, 2003: 1; RGO, 2006: 72; SenterNovem, 2004: 30; van der Greef, 2008: 9, 14). However, there remain concerns about the reproducibility of the results (Barrier et al., 2006: 4685). Proponents of 'personalized medicine' hold that targeted approaches will be more cost-effective than population-level interventions (Colditz et al., 2006: 79). Their opponents stress that unusually small 'personalized' markets provide no economic incentives to the pharmaceutical industry (interviewee A). Drug development presents a challenge, as in the many stages (trials) in pre-clinical drug development initially promising drug candidates can ultimately fail. A thorough understanding of molecular markers is needed in trials aimed at developing drugs for subsets of the population, as if pre-selection is based on wrong markers, this may impede regulatory approval for the patient sub-population that responds to the drug (Berry, 2001: 240). These pressures and challenges could restrict pharmacogenetics-enabled drug development to only those drugs that could replace other drugs with intolerable side effects in small patient populations (RVZ, 2002b: 19, 23-24). A move toward sub-groups need not advantage specialized, small and medium-sized enterprises (SMEs), as drug development is capital-intensive and, in the Netherlands, dominated by large pharmaceutical companies with close ties to universities and academic hospitals (RGO, 2005: 58, 59).

Similarly, markets for 'personalized' food products would be too small to provide sustained profits. Competing companies can appropriate documented health claims (Clydesdale, 2004: 40). Any health claims made on foods would require human trials, which because of the medical endpoints implied are regulated as clinical ones (cf EU drug and food regulation $^{12}$ ). Existing trials organized by food companies seldom satisfy the requirements accepted in epidemiological methodologies and research design as follow-up studies of at least a couple decades are necessary (interviewee B).

Ethics From an ethical perspective, the reliability of genetic testing/screening information has been questioned: predictive testing can only provide risk estimates, not certainty. This uncertainty is due to the low penetrance of genetic variations associated with most cancers that involve variations in numbers of genes, as in sporadic colorectal cancer (Davey
Smith and Ibrahim, 2003: 1; Davey Smith et al., 2005: 1487). The outcomes of such tests could destabilize the patient, increase feelings of genetic determinism, and undermine support for public health prevention programmes (Kraft and Hunter, 2005: 1614).

Summary Colorectal cancer allows for specific and general criticism of genomics optimism. The uncertainties of 'personalized medicine' relate to a number of quite heterogeneous factors, including: (1) epidemiology, aetiology and risk prediction; (2) ancillary innovation; (3) interdisciplinary collaboration; (4) the economics of drug development; and (5) ethics. While genomics programmes (such as the NGI) either target directly, or coordinate other activities targeted at, a number of these factors (covering fundamental research, research infrastructure, academic knowledge transfer, and ethical and societal aspects), overcoming these uncertainties will probably not be a linear process. Though breakthroughs will undoubtedly accrue over time, from a policy-making point of view most funding programmes are implemented over periods which rarely exceed ten years. The question is whether enough progress toward personalized colorectal cancer healthcare will have been made over the next decade.

\section{Acknowledgement of uncertainties}

How are the uncertainties of genomics acknowledged at different levels of the Dutch life sciences governance system? To answer this question we have analyzed specifically those official documents since 2001 that represent actors' expectations of genomics-based products and paradigms. These documents include: annual reports and strategic and business plans at the levels of research and $R \& D$ institutes (the 'knowledge space', see Braun 2008a: 231), programme coordinators, funding intermediaries, charity funds; foresight reports of advisory bodies and sector councils concerning the Dutch biomedical life sciences and health policy landscape; and notes to the Second Chamber of Parliament.

Fundamental research and programme coordination The first periodic activity report of the CGC has recognized conditions and contextual factors that could increase the chances of paradigm expectations being realized: knowledge resulting from research undertaken at the CGC may serve as the basis for the development of therapeutics but the process is arduous (taking up to two decades) and many other steps and activities are necessary (CGC, 2006: 15, 57). The NGI has in its Strategic Plan Genomics 2008-2012 clearly portrayed individualized treatments based on new diagnostics and 'personalized medicines' as the future to come (NGI, 2006: 18). The 2008-2012 NGI business plan ascribes to genomics the potential to 'open $[. .$.$] the door to new treatments geared to$ 
the specific profile of the individual patient' (NGI, 2007a: 9). An interesting example of expectations generation is the 2007 annual report, where the above sentence from the previous year had been changed to [genomics] 'creates realistic expectations of new therapeutic treatments in the next ten years'; these treatments are paraphrased as 'personalized medicine' (NGI, 2008: 33). According to interviewee D from the CGC, leading staff at the CGC were not consulted as to whether such expectations would indeed represent the cancer experts' view of the future. In these NGI documents, there is no context acknowledgement at all.

Applied research and public-private partnerships and programme coordination Neither in the annual report for 2006 of the TI Pharma, nor in the 2006 business plan of the Center for Translational Molecular Medicine (CTMM) is there an indication of the pre-conditions of genomics-based products. The CTMM presents the field of 'Molecular Medicine' [sic] as 'hold[ing] the promise' of a paradigm shift to the early detection of predisposition to diseases, cost-effective personalized treatments, and reduced side effects (CTMM, 2006: 11). There is no acknowledgement whatsoever of the uncertainties of genomics-enabled innovation as demonstrated above with respect to colorectal cancer. In the SenterNovem (the Dutch Ministry of Economic Affairs' programme coordinator) agenda for the second round of its strategic IOP Genomics programme, references are made to the almost certain impact of genomics in healthcare (Senter-Novem, 2004: 12, 28) but these are combined with reflection on enabling factors. Senter-Novem also coordinates the new 'Life Sciences en Gezondheid' programme set up in order to support innovation involving life sciences companies; in a 2008 text documenting the aims of this programme (authored by a task force whose members are from leading multi-national companies) assertive modalities ('the future will') were used to sketch out, without any context acknowledgement, the pharmacogenomic future in all its stereotypical aspects (MinEZ/Task Force Life Sciences en Gezondheid, 2008a: 5-6).

Advisory bodies and sector councils In the Dutch research system, intermediary organizations assume a strong role in agenda setting. Sectoral advisory councils represent researchers, users and government agencies and advise ministries on research policy in the particular sector and the directions research funding should take, and foresight exercises are a common responsibility (Dresner, 2002: 169171, 179; van der Meulen and Rip, 1998: 758). An early proposal of the Royal Netherlands Academy of Arts and Sciences' (KNAW) Council for the Medical Sciences (RMW) for a foresight exercise on multifactorial disorders in the genomics age reported on existing expectations of the potential of pharmacogenomics to identify sub-populations of drug responders, but also alerted to the degree of uncertainty of such expectations (KNAW-RMW, 2003: 1). The Council for Health Research (RGO) reported in their 2002 recommendations on novel applications of genetics in healthcare that neither in the short- nor in the medium-term should applications of pharmacogenetics for genetic profile-based disorder prediction be expected as there are unreliability issues (RGO, 2002: 84). The 2004 annual report of the Health Research/Health Council mixed modalities and assessments of the future: it predicted for genomics a permanent role in medical research within the near future while DNA and protein testing may become medical routine (RGO-GR, 2004: 5). The Council for Public Health and Health Care (RVZ) published in 2001 a report on medical-specialist care in the future and stated that individualized therapy was to be expected within the next 25 years (RVZ, 2001b: 50).

Summary We can trace uncertainties of genomics and pre-conditions of successful innovation and introduction in healthcare sporadically in various forward-looking documents (such as foresight reports). However, a number of such documents are still missing such context sensitivity, or there is no coherence at the level of a particular organization (such as sector councils or advisory bodies) with respect to future expectations. Where these documents acknowledge contextual factors and pre-conditions, these overlap with the categories of pre-conditions that we illustrated in the case of colorectal cancer: progress in fundamental gene-disease research; large-scale studies and (translational) integration of genetics-epidemiology; ancillary innovation in technologies and bioinformatics; availability of tissues; the long-term nature of innovation trajectories especially in healthcare and food; the problematic economics of tailoring treatment; and the integration of debates around ethical, legal and societal issues. However, the absence of such context sensitivity in a number of reports, especially at the level of highly funded programmes and public-private partnerships, should give reason for concern. These expectations serve to justify the investments, but with programme coordinators and other of these organizations becoming involved in communication with the broader

\section{However, the absence of such context sensitivity in a number of reports, especially at the level of highly funded programmes and public-private partnerships, should give reason for concern}


public (via events such as the annual Genomics Momentum meetings ${ }^{13}$ ) they may also shape societal expectations, for better or, given the uncertainties, worse.

\section{Policy impacts and policy challenges of genomics}

\section{Possible long-term and structural impacts on health policy}

The genomics euphoria may be related to the expectations work of a small number of genomic optimistics (Merikangas et al., 2006: 590, 591) or success stories of treating monogenetic disorders (interviewee E), however, we have found that these expectations continue to be reproduced in the literature. Genomics receives a major share of current Dutch life and biomedical science funding. Here, expectations align the future of both prevention and treatment of chronic disorders with prediction and tailoring. However, due to the various research and R\&D uncertainties and ethical dilemmas sketched out above, the vision of genomicsbased prediction remains uncertain. Nutrigenomics expectations of 'personalized nutrition' are becoming marginalized already, perhaps due to the complexity of diet-gene-disorder relationships (interviewee E). Nutrigenomics might be more useful for the analysis of probiotics-human cell interaction (Marco et al., 2006: 205) and toxicity checks (Ahmed, 2003: 491). The complexity of very fundamental processes to which genomics and other omics tools are applied must not be underestimated, and will require high levels of investment into the omics infrastructures and research community. However, these high levels will be a costly option, not only in financial terms, but also in long-term and indirect impacts.

The visions articulated in health policy organizations such as life-course perspectives require a multi-disciplinary knowledge base and a combination of prevention and treatment, not a domination of either. From a historical perspective, the impacts of genomics on the understanding of chronic disorders are one chapter in the process of the geneticization of disorder aetiology. From this perspective, the geneticization of epidemiology is nothing new: the challenge for 20th century epidemiology to satisfactorily explain environment-disorder relationships led to the emergence of genetic epidemiology since 1980 , and the study of genetic associations (Buchanan et al., 2006: 562; Clayton and McKeigue, 2001: 1358-1359). Researchers in the field were urged to acquire knowledge of pathogenetic mechanisms in order to articulate possibilities of prevention (Muir, 1990: 6446; Charlton, 1996: 623, 625). However, other scholars have called for the integration of genetic and environmental perspectives on disease aetiology enabling the understanding of the causation of disease at both the population and the individual levels, and for close cooperation between the aetiology and the risk factor-oriented branches of epidemiology (Susser and Susser, 1996: 668). We consider this an argument for retaining some form of balance between understanding basic genetic and molecular mechanisms on the one hand (which helps developing new treatments), and articulating prevention strategies on the other. New contexts of causation have emerged, such as international migration and global climate change (Pearce, 1996: 681; 2007: 714; Rockhill et al., 2000: 177); changes in national cancer incidence remain difficult to explain by genetics alone (Potter, 2003: 691). Functional variation can have a subtle effect on individual cancer risk but may be highly prevalent in a population, and therefore have a large population impact (Brennan, 2002: 381-382).

Our concern is that the focus on genomics might lead to 'strategic imbalances': fields and projects that produce knowledge for disorder treatment are favored while prevention-oriented research has funding problems; in the long-term the knowledge base that a future integrated (prevention and treatment oriented) healthcare system requires will suffer. One may accept this as a characteristic dynamic of research funding, which follows hot topics emerging in certain promising fields (as interviewee I suggested). Access to funding seems to be comparatively easier where epidemiologists cooperate with molecular biologists and incorporate molecular data into their research, and where the study objects are the more common cancers (interviewee F). We cannot yet quantify these shifts in the science system, as the application of scientometric methods is outside our research, but in our interviews we have picked up signals from nutritional and cancer epidemiologists who have expressed concerns about funding prospects for research on diet, lifestyle, and prevention. Funding has shifted partly towards international intermediaries (such as the World Cancer Research Fund; interviewee E). The need for longitudinal population and cohort studies in order to assess gene-environment relationships is in conflict with funding mechanisms that favor short- and mediumterm projects (KNAW-RMW, 2003: 2; 2005: 28). RIVM's 'life-course perspective' necessitates longitudinal analyses of disorder development in age cohorts. However, as of 2006 such longitudinal analyses were scarce (RIVM, 2006: 15, 111-112, $165,168)$.

We do not intend to argue in favor of disease management or life-course perspectives, nor do we intend to argue against genomics per se. However, we want to point out that de-contextualized genomics euphoria can create constraints on other policy sectors, such as health policy, especially if actors in the Dutch healthcare sector should come to align around (definitions of) disease management, integrated care, or life-course perspective. In our view, the major issue that science and health policy must 


\section{The major issue that science and health policy must address over the next few years is expectations management}

address over the next few years is expectations management. This has to manifest in robust scenario building and policy coordination across the borders of science and health policy sectors. In the following section, we suggest useful approaches emerging from the broad literature. We refer to the situation and developments in the Netherlands and elsewhere.

\section{Expectations management: \\ tools, communicative forms, contents and aims}

Any future of genomics in healthcare innovation will depend on research dynamics in combination with developments in the network of pre-conditions. Rather than using expectations endogenous to the emerging genomics research community to sketch out glorious futures of personalized health and molecular medicine, the uncertainties and potential futures of genomics in context need to be embraced. This interplay cannot be modeled in a mechanistic sense, but scenarios can be used to explore these futures: which can range from personalized health scenarios to niche scenarios for genomics. Scenario building can be located in many different contexts, such as the articulation of strategic plans at research institute and programme levels, or innovation sector or societal foresight exercises. Scenario building must involve the different stakeholders and representatives of research and innovation sectors, which can have an impact on future innovation trajectories, as much for reasons of democratic inclusion in the scenario building process as for the expertise these different constituencies have to offer.

Tools Scenario building for life and health sciences research and innovation can make use of a growing body of knowledge and tools from the strategic intelligence and policy studies literatures. Policy analysts have described the increasing value of strategic intelligence tools (including foresight, scenario building, and technology assessment) for both preparation and coordination of science and technology policy (Braun, 2008b: 295; Laredo, 2003: 10; Tait and Williams, 1999: 102). Science, technology and innovation scholars have contributed insights regarding the dynamics of fundamental research (scientific credibility cycle, see Rip, 1994; Wouters, 1997) and the emergence of novel paths of technological innovation (Robinson, 2006). Fundamental knowledge production (exploration) leads to the build-up of a knowledge reservoir with potentially relevant elements, but actual selection and exploitation are up to other actors further down the innovation chain (van der Meulen and Rip, 1998: 67). Scenario building can anticipate possible paths of such knowledge take-up (cf Robinson and Propp, 2008). With respect to language, expectations researchers have made efforts at operationalizing modalities ('could, might, will, shall') as indicators of perceptions of the probability of expectations (Robinson et al., 2007); whenever there is a degree of uncertainty to expectations, one should refrain from assertive statements ('the future will...') and use other modalities.

In genomics, learning has taken place over the past few years about goals that seem more realistic, and the time spans and other efforts implied in order to realize these goals (interviewees $\mathrm{G}$ and $\mathrm{N}$ ). Researchers themselves have realized the need to acknowledge the complexities and uncertainties of promising new fields (Davey Smith et al., 2005: 1495; Palmer, 2004: 926; Khoury and Gwinn, 2006: 1363), and are becoming engaged in the articulation of more realistic scenarios of product innovation, such as genetic profiling (Janssens and van Duijn, 2008; interviewees $\mathrm{K}, \mathrm{L}$ and $\mathrm{N}$ ).

Issues located in the pre-conditions network are also addressed more comprehensively in ethical, legal and societal aspects/issues programmes such as the Center for Society and Genomics in the Netherlands, which interfaces with ongoing research activities in 'red' (life sciences), 'green' (food) and 'white' (industrial) genomics (e.g. Stol et al., forthcoming).

Vision assessment (Grunwald, 2007) has emerged as a multi-disciplinary approach to both evaluation and articulation of paradigm expectations. Public participation and research agenda setting are a recurring theme in policy studies (Caron-Flinterman et al., 2006; Mayer, 2003; Weale, 2001). Involvement of multiple stakeholders in agenda building is expected to improve the societal acceptance of genetic testing (RGO, 2006: 44, 50). Expectations and demands of patients, consumers, or concerned citizens are used as reference points for deliberative agenda setting, and these processes can be organized as broad forums (Edler et al., 2006) or dedicated userproducer interactions (Boon, 2007; Nahuis et al., 2009, Moors et al., 2008).

Communicative forms Nightingale and Scott (2007: 548) suggested in this journal that in order to address the mismatch between ongoing research and research that society requires (otherwise known as the 'relevance gap') 'explicit relevance criteria [be inserted] within peer review'. However, relevance criteria will only contribute to further exaggerating of certain expectations as researchers will repeat what peer reviewers (now as wardens of societal needs) will want to hear. That is why we advocate that researchers be asked to add 'relevance conditions' to their proposals, ie a listing of scientific, 
technological, regulatory and socio-ethical preconditions under which product and paradigm expectations could become relevant for society. The conceptual framework that we developed for the mapping of expectations can also aid in the improvement of the articulation of expectations. For search, product and paradigm expectations, different and overlapping sets of factors located in science, technology, regulation and policy, and society will be important. As an example, a forward-looking statement in a research proposal could read as follows: 'Our research could lead to novel drugs inhibiting the $[\mathrm{x}, \mathrm{y}, \mathrm{z}]$ growth factor in colorectal cancer patients expressing this factor if in vitro and in vivo experiments will have established this effect sufficiently, and if companies will have decided affirmatively on the economic feasibility of comparatively smaller (targeted) drug markets.'

Contents and aims The willingness to accept a multiplicity of futures should lead to assessments of genomics research and innovation programmes in terms of not only its uncertain potential but also the unintended impacts on research in other life sciences fields, and on healthcare visions. Both the multiple pre-conditions of genomics-enabled research and innovation, and the unintended impacts of genomics, will be, as we hypothesize, located across a variety of policy sectors. These can include: health care (concerning healthcare visions and their knowledge base); economic affairs (concerning innovation policies and their expectations); science and education (concerning research policy and the allocation of funds to programmes); or legal matters (concerning the legal implications of screening and testing).

As some of these departments have their own organizations involved in programme coordination (ZonMw for the Ministry of Healthcare, Welfare and Sports; Senter-Novem for the Ministry of Economic Affairs), the range of organizations involved calls for better policy coordination. The latter has been discussed in the pages of Science and Public Policy; among other journals. Braun has presented a number of institutional options for promoting policy coordination including coordination at the ministerial, intermediary agency, and cabinet levels (Braun, 2008a: 233-237; 2008b: 291). While these reflections are worthwhile, we would like to advocate a different entrance point, namely the endogenous factors shaping policy. Studies of national style (Halffman, 2005) and political cultures (Dresner, 2002) have highlighted the consensus-oriented traits of Dutch politics and policy-making: the 'polder model' (Dresner, 2002: 169-170). Thus, the initiation of a multi-actor process aimed at negotiating the eventual road to policy integration may be crucial.

One aim of scenario building must be to explore strategies of avoiding (or at least moderating) the unintended impacts of genomics on healthcare policy visions. For example, the positive effects of prioritization of genomics funding on other sectors can be explored. Merikangas and Risch (2003: 601) have suggested directing high priority genomics funding to diseases that cannot be treated or prevented based on environmental changes (such as breast cancer, Alzheimer's disease, type 1 diabetes). However, prioritizing fundamental research will not be easy (interviewee B). The funds freed up could thus be used to finance expensive infrastructure and long-term projects in epidemiology (case-control studies, multi-center studies, international integration of cohort and tissue databases (Brennan, 2002: 385, 387; KNAW-MFA, 2006: 95)).

\section{Notes}

1. The Human Gemome Project, available at <http://www.ornl. gov/sci/techresources/Human_Genome/home.shtml>, last accessed 15 October 2008.

2. Primary and secondary prevention cannot always clearly be distinguished (Perera, 2000: 607).

3. Our interviewees were:

A: microbiologist; co-author of RVZ, 2002b (Utrecht, 21 and 28 February 2007).

B: valorization officer, Utrecht University/Utrecht Holdings B.V./Cancer Genomics Center (Utrecht, 31 May 2007).

$\mathrm{C}$ and D: molecular biologist and cell biologist, Cancer Genomics Center, Utrecht (Utrecht, 19 July 2007; additional interview with D, Utrecht, 25 September 2008).

E: colorectal cancer epidemiologist, Nijmegen/Wageningen University (Nijmegen, 12 September 2007; Wageningen, 9 October 2008).

F: colorectal cancer epidemiologist, Maastricht University (Maastricht, 30 October 2007).

G: staff member, Center for Society and Genomics, Nijmegen University (Nijmegen, 5 September 2008).

$\mathrm{H}$ : molecular geneticist, Hubrecht Institute for Developmental Biology and Stem Cell Research (Utrecht, 2 October 2008).

I: research manager, Dutch Cancer Institute/NKI, Amsterdam (Amsterdam, 2 October 2008).

$\mathrm{K}$ and L: staff members, Rathenau Institute, The Hague (The Hague, 8 October 2008).

M: medical oncologist, Ersmus MC/Daniel den Hoed Cancer Clinic, Rotterdam (Rotterdam, 8 October 2008).

$\mathrm{N}$ : epidemiologist, Erasmus Medical Center, Rotterdam (Rotterdam, 13 October 2008; additional telephone conversation, 17 October 2008).

4. TIFN. Available at <http://www.tifn.nl/webdb/Overview ProjectPages?readform\&Page $=$ A003\&Prog $=A>$, last accessed 19 July 2008.

5. Senter-Novem. Available at <http://www.senternovem.nl/fnd/ Nieuws/index.asp>, last accessed 19 July 2008.

6. Cancer Genomics Center. Available at <http://www. cancergenomics.nl/process.php?page=publications $>$, last acessed 4 July 2008.

7. 'Medicine' has two meanings in English, i.e. treatment (excluding diagnosis) and healthcare (personal communication, Douglas Robinson). In addition, medicine can be more than a particular drug, including herbal remedies, and other forms of alternative medicine.

8. See also the diagram in Ginsburg and McCarthy (2001: 494).

9. Cf the statistics published on the websites of Cancer Research UK (available at <http://www.cancerresearchuk.org/>, last accessed 1 July 2008), Deutsche Krebshilfe e.V. (available at <http://www.krebshilfe.de/startseite-dkh.html>, last accessed 1 July 2008), the American Association for Cancer Research; (available at <http://www.aacr.org/default.aspx>, last accessed 1 July 2008) and the Canadian Cancer Society (available at <http://www.cancer.ca/ccs/internet/niw_splash/ 0\%2C\%2C3172\%2C00.html>, last accessed 1 July 2008).

10. The components mentioned are being tested in ongoing clinical trials registered at the US-based Clinical Trials Database. Data was collected on 29 June 2008. Available at $<$ http://clinicaltrials.gov/ct/info/about>, last accessed 29 June 2008. 
11. Available at <http://www.parelsnoer.org/index.php/page/ English>, last accessed 29 July 2008.

12. Cf European Commission Food Law Portal. Available at <http://ec.europa.eu/food/food/foodlaw/index en.htm>, last accessed 1 July 2008

13. Genomics Momentum. Available at <http://www.gm2008. org/>, last accessed 15 October 2008.

\section{References}

Abbott, Alison 2001. And now for the proteome... Nature, 409(6822), 747

Ahmed, Farid E 2003. Genetically modified probiotics in foods. Trends in Biotechnology, 21(11), 491-497.

Anderson, Annie S 2002. Genomics and dietary behaviour - opportunities and challenges? Journal of Human Nutrition and Dietetics, 15(5), 321-322.

Baglioni, Silvana and Maurizio Genuardi 2004. Simple and complex genetics of colorectal cancer susceptibility. American Journal of Medical Genetics Part C (Semin. Med. Genet.), 129C(1), 35-43.

Barrier, Alain, Pierre-Yves Boelle, Francois Roser, Jennifer Gregg, Chantal Tse, Didier Brault, Francois Lacaine, Sidney Houry, Michel Huguier, Brigitte Franc, Antoine Flahault, Antoinette Lemoine and Sandrine Dudoit 2006. Stage II colon cancer prognosis prediction by tumor gene expression profiling Journal of Clinical Oncology, 24(29), 4685-4691.

Bencko, Vladimír 2007. Environmental epidemiology, present chances and challenges for future. Central European Journal of Public Health Supplement, 15, S6-S8.

Berry, Suzanne 2001. Meeting report: The impact of genomics on drug discovery and development. Keystone meeting, 2-7 February 2001, Santa Fe, New Mexico. Trends in Biotechnology, 19(7), 239-240.

Boon, Wouter 2007. Demand articulation in emerging pharmaceutical technologies: a comparison of two intermediary organizations. Presentation at the Third Annual Corsage Workshop 'Contingencies of genomics - finding roads into the future', 13 December 2007. Utrecht: De Witte Vosch.

Bracken, Michael B 2005. Genomic epidemiology of complex disease: the need for an electronic evidence-based approach to research synthesis. American Journal of Epidemiology, 162(4), 297-301.

Braun, Dietmar 2008a. Organising the political coordination of knowledge and innovation policies. Science and Public Policy, 35(4), 227-239.

Braun, Dietmar 2008b. Lessons on the political coordination of knowledge and innovation policies. Science and Public Policy, 35(4), 289-298.

Brennan, Paul 2002. Gene-environment interaction and aetiology of cancer: what does it mean and how can we measure it? Carcinogenesis, 23(3), 381-387.

Brower, Vicki 2003. Evidence of efficacy: researchers investigating markers for angiogenesis inhibitors. Journal of the National Cancer Institute, 95(19), 1425-1427.

Brown, Nik, Arie Rip and Harro van Lente 2003. Expectations in and about science and technology. A background paper for the 'Expectations' Workshop, 13-14 June 2003, Utrecht. Buchanan, Anne V, Kenneth M Weiss and Stephanie M Fullerton 2006. Dissecting complex disease: the quest for the philosopher's stone? International Journal of Epidemiology, 35(3), 562-571.

Canda, A Erdem and Ziya Kirkali 2006. Current management of renal cell carcinoma and targeted therapy. Urology Journal, 3(1), 1-14

Campbell, Harry and Teri Manolio 2007. Commentary: Rare alleles, modest genetic effects and the need for collaboration. International Journal of Epidemiology, 36(2), 445-448.

Cardon, Lon R and Hugh Watkins 2000. Waiting for the working draft from the human genome project. A huge achievement but not of immediate medical use. British Medical Journal, 320(7244), 1223-1224.

Cardoso, J, J Boer, H Morreau and R Fodde. 2007. Expression and genomic profiling of colorectal cancer. Biochimica et Biophysica Acta, 1775(1), 103-137.

Caron-Flinterman, J Francisca, Jacqueline E W Broerse, Julia Teerling, Melissa $L Y$ van Alst, Simon Klaasen, L Edwin Swart and Joske F G Bunders 2006. Stakeholder participation in health research agenda setting: the case of asthma and COPD research in the Netherlands. Science and Public Policy, 33(4), 291-304.

CGC (Cancer Genomics Centre) 2006. Report 2002-2005. CGC: Utrecht.

Chandonia, John-Marc and Steven E Brenner 2006. The impact of structural genomics: expectations and outcomes. Science, 311(5759), January 20, 347-351.

Charlton, Bruce G 1996. The scope and nature of epidemiology. Journal of Clinical Epidemiology, 49(6), 623-626.

Christensen, Damaris 2004. Dietary prevention of cancer: a smorgasbord of options for moving ahead. Journal of the National Cancer Institute, 96(11), 822-824.

Clayton, David and Paul M McKeigue 2001. Epidemiological methods for studying genes and environmental factors in complex diseases. Lancet, 358(9290), 1356-1360.

Clydesdale, Fergus 2004. Functional foods: opportunities \& challenges. Food Technology, 58(12), 35-40.

Colditz, Graham A, Thomas A Sellers and Edward Trapido 2006. Epidemiology - identifying the causes and preventability of cancer? Nature Reviews Cancer, 6(1), 75-83.

CTMM (Center for Translational Molecular Medicine) 2006. Business Plan 2006. CTMM: The Hague.

Davey Smith, George and Shah Ebrahim 2003. 'Mendelian randomization': can genetic epidemiology contribute to understanding environmental determinants of disease? International Journal of Epidemiology, 32(1), 1-22.

Davey Smith, George, Shah Ebrahim, Sarah Lewis, Anna L Hansell, Lyle J Palmer and Paul R Burton 2005. Genetic epidemiology and public health: hope, hype, and future prospects. Lancet, 366(9494), 1484-1498.

De la Chapelle, Albert 2004. Genetic predisposition to colorectal cancer. Nature Reviews Cancer, 4(10), 769-780.

Dresner, Simon 2002. A tale of two ministers: attempts at reform of research systems in the Netherlands and the United Kingdom. Science and Public Policy, 29(3), 169-180.

Edler, Jakob, Pierre-Benoit Joly, Stefan Kuhlmann, Maria Nedeva, Tilo Propp, Arie Rip, Sascha Ruhland and Duncan Thomas 2006. Understanding 'Fora of Strategic Intelligence for Research and Innovation'. The PRIME Forum Research Project. Final Report. Available at <http://www.isi.fraunhofer. de/p/Downloads/PRIME FORUM Final_Reportv2.pdf $>$ last accessed 1 July 2008

Ginsburg, Geoffrey S and Jeanette J McCarthy 2001. Personalized medicine: revolutionizing drug discovery and patient care. Trends in Biotechnology, 19(12), December, 491-496.

Grunwald, Armin 2007. Converging technologies: Visions, increased contingencies of the conditio humana, and search for orientation. Futures, 39(4), 380-392.

Halffman, Willem 2005. Science-policy boundaries: national styles? Science and Public Policy, 32(6), 457-467.

Herceg, Zdenko 2007. Epigenetics and cancer: towards an evaluation of the impact of environmental and dietary factors. Mutagenesis, 22(2), 91-103.

International SNP Map Working Group 2001. A map of human genome sequence variation containing 1.42 million single nucleotide polymorphisms. Nature, 409(6822), 928-933.

Janssens, Cecile J W and Cornelia M van Duijn 2008. Genomebased prediction of common diseases: advances and prospects. Human Molecular Genetics, 17(R2), 165-172.

Jorde, Lynn B, John C Carey, Michael J Bamshad and Raymond L White 2006. Medical Genetics, 3rd edn. St Louis, MO: Mosby.

Khoury, Muin J, Robert Millikan, Julian Little and Marta Gwinn 2004. The emergence of epidemiology in the genomics age. International Journal of Epidemiology 33(5), 936-944.

Khoury, Muin J and Marta Gwinn 2006. Genomics, epidemiology, and common complex diseases: let's not throw out the baby with the bathwater! International Journal of Epidemiology, 35(5), 1363-1364.

KNAW (Koninklijke Nederlandse Akademie van Wetenschappen/Royal Netherlands Academy of Arts and Sciences). Available at <http://www.knaw.nl/cfdata/adviesraden/ adviesraden.cfm>, last accessed 21 July 2008 .

KNAW-RMW (Raad voor de Medische Wetenschap) 2003 Voorstel voor een verkenning 'Multifactoriële aandoeningen in het genomics tijdperk'. Amsterdam.

KNAW-RMW 2005. Erop of eronder: Financiering van (bio)medisch wetenschappelijk onderzoek. Amsterdam.

KNAW-MFA (Verkenningscommissie Multifactoriële aandoeningen) 2006. Multifactoriële aandoeningen in het 
genomics-tijdperk. Amsterdam.

KNMG (Koninklijke Nederlandsche Maatschappij tot bevordering der Geneeskunst/Royal Dutch Medical Association) 2007. Volksgezondheid en preventie. Koninklijke Nederlandsche Maatschappij tot bevordering der Geneeskunst (KNMG): Volksgezondheid en Preventie. De visie van de KNMG. Utrecht.

Kornek, G, W Scheithauer, R Anghel, G Bodoky, F Ciardiello, T Ciuleanu, R Glynne-Jones, T Gruenberger, I Koza, J Ocvirk, L Petruzelka, G Poston, G Ramadori, W Schmiegel, S Segaert, $\mathrm{J}$ Tabernero, H Zwierzina and C Zielinski 2008. Consensus on the medical treatment of colon cancer. Magazine of European Medical Oncology, 1(2), 79-90.

Kraft, Peter and David Hunter 2005. Integrating epidemiology and genetic association: the challenge of gene-environment interaction. Philosophical Transactions of the Royal Society - Biological Sciences, 360(1460), 1609-1616.

Kussmann, Martin, Frederic Raymond and Michael Affolter 2006. Omics-driven biomarker discovery in nutrition and health. Journal of Biotechnology, 124(4), August, 758-787.

Larédo, Philippe 2003. Six major challenges facing public intervention in higher education, science, technology and innovation. Science and Public Policy, 30(1), 4-12.

Lepori, Benedetto, Peter van den Besselaar, Michael Dinges, Bianca Potì, Emanuela Reale, Stig Slipersæter, Jean Thèves and Barend van der Meulen 2007. Comparing the evolution of national research policies: what patterns of change? Science and Public Policy, 34(6), 372-388.

Marco, Maria L, Sonja Pavan and Michiel Kleerebezem 2006. Towards understanding molecular modes of probiotic action. Current Opinion in Biotechnology, 17(2), 204-210.

Mason, Anne, Michael Drummond and Adrian Towse 1999. Is disease management relevant in Europe: some evidence from the United Kingdom. Health Policy, 48(1), 69-77.

Mayer, Sue 2003. Science out of step with the public: the need for public accountability of science in the UK. Science and Public Policy, 30(3), 177-181.

Merikangas, Kathleen Ries and Neil Risch 2003. Genomic priorities and public health. Science, 302(5645), October 24, 599-601.

Merikangas, Kathleen Ries, Nancy C P Low and John Hardy 2006. Commentary: Understanding sources of complexity in chronic diseases - the importance of integration of genetics and epidemiology. International Journal of Epidemiology, 35(3), 590-592.

MinEZ (Ministerie Economische Zaken/Ministry of Economic Affairs)/SenterNovem.

2006. Kamerstukken: 'Investeren in Innovatieprogramma's'. 3de Voortgangsrapportage aan het IP over de Sleutelgebieden-aanpak. The Hague.

2007. Kamerstukken: 'Innovatieprogramma's - Volop in bedrijf'. 4de Voortgangsrapportage aan het IP over de Sleutelgebieden-aanpak. The Hague.

MinEZ/TWA Network 2006. Technological innovations in the (preventive) health sector: examples and trends in the Netherlands. The Hague.

MinEZ/Task Force Life Sciences en Gezondheid

2008a. Innovation Intelligence Life Sciences \& Gezondheid. The Hague.

2008b. Capitalizing on Knowledge. Presentation at the BioBusinessEvent, 21 May 2008, Amsterdam RAl. Available at <http://www.lifesciencesgezondheid.nl/downloads. html>, last accessed 5 July 2008.

MinOCW (Ministerie van Onderwijs, Cultuur en Wetenschappen/ Ministry of Education, Culture and Science) 2001. Convenant Nationaal Regieorgaan Genomics. Zoetermeer.

MinVWS (Ministerie van Volksgezondheid, Welzijn en Sport/ Ministry of Health, Welfare and Sport). Available at <http://www.minvws.nl/kamerstukken/pg/2006/derde-preventie programma-zonmw.asp>, last accessed 21 July 2008.

2007a. Gezond zijn, gezond blijven. Een visie op gezondheid en preventie. The Hague.

MinVWS 2007b. Kaderbrief 2007-2011: kabinetsvisie op gezondheid en preventie (24 September 2007). The Hague.

Moors, Ellen H M, Wouter Boon, Roel Nahuis and Rens Vandeberg 2008. User-producer interactions in emerging pharmaceutical and food innovations. International Journal of Innovation Management, 12(3), 1-28.

Muir, C S 1990. Epidemiology, basic science, and the prevention of cancer: Implications for the future. Cancer Research,
50(20), 6441-6448.

Nahuis, R, Ellen H M Moors and Ruud E H M Smits 2009. User producer interaction in context: A classification. ISU Working Paper No. 09.01, Utrecht University: Department of Innovation and Environmental Studies. Available at <http://www.geo. uu.nl/isu/pdf/isu0901.pdf>, last accessed 19 March 2009.

National Cancer Institute (USA) 2006. Cancer Stat Fact Sheets: Cancer of the Colon and Rectum. Available at <http:// www.cancer.gov> and <http://seer.cancer.gov/statfacts/html/ colorect.html>, last accessed 1 July 2008.

Nebert, Daniel W and Eula Bingham 2001. Pharmacogenomics: out of the lab and into the community. Trends in Biotechnology, 19(12), 519-523.

NGI (Netherlands Genomics Initiative/Regie-Orgaan Genomics) 2006. Strategic Plan Genomics 2008-2012. The Hague. 2007a. NGI Business Plan 2008-2012. The Hague. 2007b. Making the most of genomics. The Hague. 2008. Annual Report 2007. The Hague.

Nightingale, Paul and Alister Scott 2007. Peer review and the relevance gap: ten suggestions for policy-makers. Science and Public Policy, 34(8), 543-553.

Palmer, Lyle J 2004. The new epidemiology: putting the pieces together in complex disease aetiology. International Journal of Epidemiology, 33(5), 925-928.

Pearce, Neil 1996. Traditional epidemiology, modern epidemiology, and public health. American Journal of Public Health, 86(5), 678-683.

Pearce, Neil 2007. Commentary: The rise and rise of corporate epidemiology and the narrowing of epidemiology's vision. International Journal of Epidemiology, 36(4), 713-717.

Perera, Frederica P 2000. Molecular epidemiology: On the path to prevention? Journal of the National Cancer Institute, 92(8), $602-612$.

Peto, Julian 2001. Cancer epidemiology in the last century and the next decade. Nature, 411(6835), 390-395.

Pohl, Alexandra, Wu Ahang, Yan Ning, Philipp C Manegold, Georg Lurje and Heinz-Josef Lenz. 2008. Targeting metastatic colorectal cancer in 2008: A long way from 5-FU. Oncology, 22(4), April 15.

Potter, John D 2003. Epidemiology, cancer genetics and microarrays: making correct inferences, using appropriate designs. Trends in Genetics, 19(12), 690-695.

RGO (Raad voor Gezondheidsonderzoek/Council for Health Research)

2001. Advies Preventieonderzoek. The Hague: RGO.

2002. Advies Nieuwe toepassingen van genetische kennis in de gezondheidszorg: Welke kennis is nodig? The Hague: RGO.

2005. Advies Kennisinfrastructuur Farmaceutische Zorg. The Hague: RGO.

2006. Advies Onderzoeksagenda Medische Biotechnologie. The Hague: RGO.

2007. Advies Translationeel onderzoek in Nederland. Van kennis naar kliniek. The Hague.

RGO/GR (Raad voor Gezondheidsonderzoek/Gezondheidsraad/ Council for Health Research/Health Council) 2004. Annual Report on Genomics nr. 1. The Hague: RGO.

Rip, Arie 1994. The republic of science in the 1990s. Higher Education, 28(3), 3-23.

Rist, Manuela J, Uwe Wenzel and Hannelore Daniel 2006. Nutrition and food science go genomic. Trends in Biotechnology, 24(4), 172-178.

RIVM (Rijksinstituut voor Volksgezondheid en Milieu/National Institute for Public Health and the Environment) 2006. Zorg voor gezondheid. Volksgezondheid Toekomst Verkenning 2006. Bilthoven: Centrum voor Volksgezondheid Toekomst Verkenningen/RIVM. Available at <http://www.rivm.nl/en/ aboutrivm/>, last accessed 24 July 2008.

Roberts, David C 2002. Biomarkers, yesterday, today and tomorrow: the basis for health claims. Asia Pacific Journal of Clinical Nutrition, 11(2), S87-89.

Roberts, Matthew-Allan, David M Mutch and J Bruce German 2001. Genomics: food and nutrition. Current Opinion in Biotechnology, 12(5), 516-522.

Robinson, Douglas K R 2006. The use of the path concept and emerging irreversibilities in the analysis and modulation of nanotechnologies. Paper presented at EIASM Workshop on Organising Paths - Paths of Organising, 3-4 November 2006, Berlin.

Robinson, Douglas K R, Martin Ruivenkamp and Arie Rip 2007. Tracking the evolution of new and emerging S\&T via 
statement-linkages: Vision assessment in molecular machines. Scientometrics, 70(3), 831-858.

Robinson, Douglas K R and Tilo Propp 2008. Multi-path mapping for alignment strategies in emerging science and technologies. Technological Forecasting and Social Change, 75(4), 517538.

Rockhill, B, I Kawachi and G A Colditz 2000. Individual risk prediction and population-wide disease prevention. Epidemiological Reviews, 22(1), 176-180.

RVZ (Raad voor de Volksgezondheid en Zorg/Council for Public Health and Health Care)

2001a. Advies: Medisch-specialistische zorg in de toekomst. The Hague: RVZ.

2001b. Dossier Medisch-specialistische zorg in de toekomst. The Hague: RVZ.

2002a. Biowetenschap en beleid. Advies uitgebracht door de Raad voor de Volksgezondheid en Zorg aan de minister van Volksgezondheid, Welzijn en Sport. Zoetermeer.

2002b. De biofarmaceutische industrie. Ontwikkelingen en gevolgen voor de gezondheidszorg. Achtergrondstudie uitgebracht door de Raad voor de Volksgezondheid en Zorg bij het verkennend advies Biowetenschap en beleid. Zoetermeer.

Senter-Novem

2004. Tweede Meerjarenprogramma IOP Genomics - Capture the potential of genomics. The Hague: Programmacommissie IOP Genomics.

2008. Jaarverslag 2007. The Hague.

Simopoulos, Artemis P 2002. Genetic variation and dietary response: Nutrigenetics/nutrigenomics. Asia Pacific Journal of Clinical Nutrition, 11(S6), S117-128.

Stol, Yrrah H, Marjan J Westerman and Rien M J P A Janssens (forthcoming). Informing family members about a hereditary cancer predisposition: attitudes and practice among clinical geneticists.

Tait, Joyce and Robin Williams 1999. Policy approaches to research and development: foresight, framework and competitiveness. Science and Public Policy, 26(2), 101-112.

Tijdelijke Adviescommissie Kennisinfrastructuur Genomics (Temporary Advisory Commission Knowledge Infrastructure Genomics) 2001. The Hague: Advies.

Susser, Menvyn and Ezra Susser 1996. Choosing a future for epidemiology: I. Eras and paradigms. American Journal of Public Health, 86(5), 668-673.

TI (Top Institute) Pharma 2007. Annual Report 2006. Leiden.
Van der Greef, Jan 2008. System thinking, a gateway to the future of Medicine. Presentation at the TI Pharma Workshop 'A systems view on the future of medicine: inspiration from Chinese Medicine?' Leiden, 23 June. Available at $<$ http://www.tipharma.com/pro1/general/start.asp?i=7\&j=3\&k= $0 \& p=0 \&$ itemid $=308>$, last accessed 19 July 2008.

Van der Valk, Tessa, Ellen H M Moors and Marius T H Meeus 2009. Conceptualizing patterns in the dynamics of emerging technologies: The case of biotechnology developments in the Netherlands. Technovation, 29(4), 247-264.

Van der Meulen, Barend and Arie Rip 1998. Mediation in the Dutch science system. Research Policy, 27(8), 757-769.

Van Lente, Harro 1993. Promising Technology - The Dynamics of Expectations in Technological Developments. Delft: Eburon Press.

Van Ommen, Ben and Rob Stierum 2002. Nutrigenomics: exploiting systems biology in the nutrition and health arena. Current Opinion in Biotechnology, 13(5), 517-521.

Weale, Albert 2001. Science advice, democratic responsiveness and public policy. Science and Public Policy, 28(6), 413-421.

Weingarten, Scott R, James M Henning, Enkhe Badamgarav, Kevin Knight, Vic Hasselblad, Anacleto Gano Jr, and Joshua J Ofman 2002. Interventions used in disease management programmes for patients with chronic illness - which ones work? Meta-analysis of published reports. British Medical Journal, 325(7370), October 26.

World Cancer Research Fund/American Institute for Cancer Research (WCRF/AICR) 2007. Food, Nutrition, Physical Activity, and the Prevention of Cancer: a Global Perspective. Washington DC: AICR.

Wouters, Paul 1997. Citation cycles and peer review cycles. Scientometrics, 38(1), 39-55.

Yun, S H 2004. Molecular targeted therapy in colorectal cancer. Journal of the Korean Society for Coloproctology, 20(3), 180-188.

ZonMw (Zorgonderzoek Nederland/Medische Wetenschappen/ Netherlands Organisation for Health Research and Development) Available at <http://www.zonmw.nl/en/>, last accessed 21 July 2008

2006. Voorstel ZonMw 3e Programma Preventie 2008-2011. The Hague: ZonMw.

2008a. Jaarplan ZonMw 2008. Programmarapportages, deel II. 2nd edn. The Hague: ZonMw.

2008b. Diseasemanagement chronische ziekten. The Hague: ZonMw. 